\title{
Komparasi Pengaruh Langsung dan Tidak Langsung Merek dan Kualitas Produk terhadap Kepercayaan Konsumen dan Loyalitas Pelanggan Produk Tas Elizabeth di Wilayah Kota Jember
}

\author{
(Comparative Direct Effect and Indirect Effect Brand and Product Quality to Consumer of \\ Confidence and Consumer of Loyalty Product Elizabeth in the City of Jember)
}

\author{
Evrylia Tri Purnama Sari, Imam Suroso*, Ketut Indraningrat \\ Manajemen, Fakultas Ekonomi dan Bisnis, Universitas Jember (UNEJ) \\ Jln. Kalimantan 37, Jember 68121 \\ E-mail: evrytabanyu@gmail.com
}

\begin{abstract}
Abstrak
Penelitian ini bertujuan untuk mengkomparasikan pengaruh langsung dan tidak langsung antara merek, kualitas produk terhadap kepercayaan konsumen dan loyalitas pelanggan pada sebuah produk merek tas Elizabeth di Wilayah Kota Jember.Penelitian ini dikategorikan sebagai penelitian penjelasan (explanatory research). Populasi dalam penelitian ini ditentukan jumlahnya dengan cara indikator dikalikan 15 parameter sehingga sampel $\mathrm{n}=7 \times 15=105$, dengan sampling purposive yaitu pelanggan tas Elizabeth di Wilayah Kota Jember. Data dikumpulkan menggunakan kuesioner sementara analisis data dengan SEM. Hasil penelitian ini menunjukkan bahwa pengaruh lansung merek terhadap loyalitas pelanggan sebesar 0,267 sementara pengaruh tidak lansung merek terhadap loyalitas pelanggan sebesar 0,443 melalui kepercayaan pelanggan. Pengaruh lansung kualitas terhadap loyalitas pelanggan sebesar 1,022 sementara pengaruh tidak lansung kualitas terhadap loyalitas sebesar 0,049 melalui kepercayaan. Kesimpulan dari penelitian in bahwa merek dan kualitas produk berpengaruh terhadap kepercayaan pelanggan dan loyalitas pelanggan produk tas Elizabeth di wilayah Kota Jember. Perusahaan perlu memperhatikan kualitas produk untuk meningkatkan kepercayaan dan loyalitas pelanggan.
\end{abstract}

Kata kunci: Kualitas Produk, Merek, Kepercayaan, Loyalitas

\begin{abstract}
This study aimed to compare the direct and indirect influence between the brand, the quality of product to consumer confidence and customer loyalty in a bag branded products in the Elizabeth City area is categorized as research Jember.Penelitian explanation (explanatory research). The population in this study quantified by means of indicator multiplied by 15 parameters so that the sample $n=7 \times 15=105$, with a purposive sampling bag subscribers Elizabeth City Regional Jember. Data were collected using a questionnaire while the data analysis by SEM. The results of this study showed that the direct influence of brand on customer loyalty by 0.267 while not directly influence brand loyalty of 0.443 customers through customer confidence. Quality direct influence on customer loyalty by 1.022 while not directly influence the quality of the loyalty of 0.049 through trust. The conclusion in that brand and product quality influence on customer trust and customer loyalty Elizabeth bag products in the city of Jember. Companies need to pay attention to the quality of the product to increase the trust and loyalty of customers.
\end{abstract}

Keywords: Quality Product, Brand, Trust, Loyalty

\section{Pendahuluan}

Seiring berkembangnya era globalisasi timbul berbagai macam persaingan yang begitu ketat dari berbagai bidang di dalamnya termasuk di bidang fashion. Peranan dan kegunaan pemasaran (marketing) sebagai salah satu fungsi dalam perusahaan semakin meningkat dan penting untuk mencapai sasaran perusahaan hal ini didasarkan pada semakin penting peranan dan kegunaan pemasaran tersebut disebabkan oleh persaingan yang semakin tajam, dimana dalam beberapa tahun belakangan ini persaingan-persaingan yang agresif, yang bersaing dalam pasar-pasar yang sama untuk merekmerek produk yang berbeda.

Brand (merek) merupakan salah satu faktor yang dipertimbangkan dalam keputusan pembelian suatu produk. Menurut UU merek No.15 Tahun 2001 pasal 1 ayat 1, merek adalah suatu tanda yang berupa gambar, nama, huruf -huruf, angka-angka, susunan warna, atau kombinasi dari unsurunsur tersebut yang memiliki daya pembeda dan digunakan dalam kegiatan perdagangan barang atau jasa. Kotler (2000:63) mengungkapkan bahwa merek merupakan sebuah nama, istilah, tanda, symbol serta desain kombinasi dari seluruhnya yang bertujuan untuk mengidentifikasi barangbarang maupun jasa dari suatu kelompok penjual dan untuk membedakan produk mereka dari para pesaing. Apabila merek sudah dikenal oleh semua kalangan akantimbul suatu keinginan untuk membeli produk tersebut. Konsumen berharap bisa mendapatkan jaminan kualitas pada setiap kesempatan penggunaan produk tersebut.Semakin banyak produk yang di jual oleh perusahaan dengan kualitas yang semakin tinggi, maka rasa puas yang diperoleh oleh pelanggan akan semakin tinggi pula. Kepercayaan merupakan faktor yang sangat penting dalam mengubah pembeli atau konsumen menjadi pelanggan pertama kali. Menurut Lau dan Lee (1999), kepercayaan atas merek adalah kesedian seseorang untuk menggantungkan dirinya pada suatu merek dan risikonya karena adanya harapan bahwa merek itu akan memberikan hasil yang positif. Konsumen yang percaya pada

\footnotetext{
* Corresponding author
} 
suatu merek, cenderung akan mempercayakan masalahnya pada merek tersebut. Kepercayaan konsumen terhadap merek (brand trust) akan berdampak terhadap kesetiaan sikap ataupun perilaku konsumen terhadap suatu merek (Chauduri \& Holbrook, 2001). Menurut Rangkuti (2002) yang mengatakan apabila konsumen beranggapan bahwa merek tertentu secara fisik berbeda dari merek pesaing, citra merek tersebut akan melekat secara terus menerus sehingga dapat membentuk kesetiaan terhadap merek tertentu yang disebut dengan loyalitas merek.

Kualitas adalah keseluruhan ciri serta sifat dari suatu produk atau pelayanan yang berpengaruh pada kemampuannya untuk memuaskan kebutuhan yang dinyatakan secara tersirat (Kotler, 1997:49). Menurut Stefanus, (2008) kepercayaan konsumen merupakan sebuah jenis refleksi emosional bagi perdagangan. Tjptono (2007:258) menyatakan bahwa kualitas produk yang berarti barang ataupun jasa berkontribusi besar pada kepuasa pelanggan, retensi pelanggan, loyalitas pelanggan, pangsa pasar, dan profitabilitas yang diperkuat dengan hasil studi yang menunjukan bahwa pangsa pasar dan perputaran asset sangat terkait dengan persepsi terhadap kualitas barang pada suatu perusahaan. Maka dengan kualitasproduk yang baik, para konsumen akan mempunyai rasa percaya dan loyal dengan produk produk yang dijual oleh perusahaan tersebut. Jika konsumen belum mengetahui kualitas produk yang dibeli, konsumen akan merasakan tingkat resiko yang tinggi dalam pembelian.

Lau dan Lee (1999) mengungkapkan bahwa kepercayaan akan melibatkan suatu harapan dari kelompok lain dan akan menyebabkan hasil yang positif, meskipun kemungkinan lain akan menyebabkan hasil yang negatif. Kepercayaan terjadi apabila seseorang memiliki kepercayan diri dalam sebuah pertukaran dengan mitra yang memiliki integritas dan dapat dipercaya (Morgan dan Hunt 1994). Sehingga kepercayaan konsumen merupakan suatu proses keyakinan dalam diri produsen untuk menawarkan sebuah produk perusahaan guna mencapai tujuan yang berlangsung dalam jangka panjang dan dapat dipercaya untuk selalu bersikap baik terhadap konsumennya. Dengan kepercayaan konsumen pemasar dapat memertahankan posisinya dalam dunia persaingan.Kepercayaan memiliki kejujuran tersendiri yaitu suatu keyakinan bahwa maksud dan motivasi seseorang akan membawa keuntungan bersama dan tidak akan menimbulkan pengaruh negatif atau merugi. Kepercayaan konsumen terhadap suatu produk akan menciptakan loyalitas pelanggan terhadap produk tersebut.

Kepercayaan konsumen terhadap merek (brand trust) akan berdampak terhadap kesetiaan sikap ataupun perilaku konsumen terhadap suatu merek (Chauduri \& Holbrook, 2001). Gilliland dan Bello (2002) mempertimbangkan kaitan antara kepercayaan, komitmen dan loyalitas, dan hasil studi Gilliland dan Bello (2002) menunjukkan kepercayaan pelanggan merupakan anteseden dari komitmen dan loyalitas pelanggan. Hasil penelitian ini tidak sependapat dengan penelitian yang telah dilakukan. Banyak pemasar yang meyakini bahwa loyalitas pelanggan pada dasarnya terbentuk karena adanya kontribusi value dan brand. Menurut Dimyati (2004: 76) menyatakan bahwa value dan brand merupakan dua faktor utama yang menjadi perangsang bagi terjadinya initial purchase(pembelian awal) dan kedua faktor tersebut sekaligus menjadi pendorong terjadinya repetition purchase (pembelian ulang).

Pada penelitian ini peneliti memilih perusahaan Elisabeth sebagai objek penelitian karena peneliti merasa bahwa semakin banyak pelanggan yang percaya terhadap produk Elizabeth terutama pada produk tas. Bahkan Elizabeth sudah diakui oleh konsumen khususnya dikota Jember. Untuk menghadapi persaingan dalam bisnis produk tas ini dan agar tetap ramai dikunjungi konsumen, maka Elizabeth harus melakukan berbagai upaya dalam kegiatan pemasarannya agar menarik dan sesuai dimata konsumen. Oleh karena itu, pihak Elizabeth harus tetap patut terhadap atribut - atribut apa saja yang mempengaruhi konsument dalam memilih suatu produk, karena pada saat ini konsumen sudah semakin kritis terhadap kemampuan suatu produk tas dalam menarik konsumennya untuk berbelanja di Elizabeth.

Dari uraian di atas maka penelitian ini nantinya akan digunakan untuk melihat bagaimana Komparasi Pengaruh Langsung Dan Tidak Langsung Antara Merek, Kualitas Produk Terhadap Kepercayaan Konsumen Dan Loyalitas Pelanggan dari sebuah produk khususnya pada tas Elizabeth di Wilayah Kota Jember.

\section{Metode}

\section{Rancangan atau Desain Penelitian}

Penelitian ini menggunakan penelitian explanatory research, yaitu suatu penelitian yang dilakukan untuk menguji hipotesis-hipotesis yang ada.

\section{Jenis dan Sumber Data}

Jenis data dalam penelitian ini adalah data primer. Data primer adalah data yang diperoleh secara langsung dari responden dengan cara membagikan kuesioner dengan objek yang sudah diteliti. Data primer dalam penelitian ini menggunakan kuesioner. Kuesioner merupakan pengumpulan data yang dilakukan dengan cara memberi seperangkat pertanyaan atau pernyataan tertulis kepada responden untuk dijawabnya. Dokumentasi merupakan teknik pengumpulan data sekunder dengan pencatatan data-data yang dianggap penting dan berhubungan dengan masalah penelitian. Teknik dokumentasi dalam penelitian ini dilakukan untuk memperoleh data-data yang berhubungan dengan sejarah dan perkembangan perusahaan, struktur organisasi, dan data-data lainnya yang sesuai dengan permasalahan penelitian

\section{Populasi dan Sampel}

Populasi dalam penelitian ini tidak diketahui secara pasti sehingga pengambilan sampel ditentukan jumlahnya dengan cara indikator dikalikan 15 parameter sehingga sampel $n=7$ $\times 15=105$, sementara pengambilan sampel ditentukan dengan purposive sampling yaitu pelanggan tas Elizabeth di Wilayah Kota Jember.

\section{Metode Analisis Data}

Analisis data dalam penelitian ini menggunakan analisis SEM. Analisis SEM memungkinkan dilakukannya analisis terhadap serangkaian hubungan secara simultan sehingga memberikan efisiensi secara statistik (Ferdinand, 2006). 


\section{Hasil dan Pembahasan}

Hasil

Deskripsi Responden

Tabel 1 Karakteristik Responden berdasarkan Jenis Kelamin

\begin{tabular}{llll}
\hline No & Jenis Kelamin & Jumlah & Persentase (\%) \\
\hline 1 & Laki-laki & 3 & 31.43 \\
2 & Perempuan & 2 & 68.57 \\
& Pendidikan Terakhir & Jumlah & Persentase (\%) \\
& SD & 1 & 0,952 \\
1 & SMP & 16 & 15,24 \\
2 & SMA & 34 & 32,38 \\
3 & Perguruan Tinggi & 54 & 51,43 \\
4 & & & \\
& Profesi & Jumlah & Persentase (\%) \\
1 & Pelajar/Maasisw & 7 & 16,19 \\
2 & Ibu rumah tangga & 9 & 18,1 \\
3 & Pegawai Negeri & 22 & 20,95 \\
4 & Pegawai Swasta & 28 & 26,67 \\
5 & Wiraswasta & 19 & 18,1 \\
\hline
\end{tabular}

Data diolah, Mei 2016

Berdasarkan tabel 1 dapat dijelaskan bahwa dari 105 responden sebagian besar adalah perempuan 72 responden. Hal ini menjelaskan bahwa tas Elizabeth banyak digunakan oleh perempuan. Tas berkaitan dengan gaya hidup dan kebiasaan yang sering dilakukan oleh perempuan yaitu shoping. Tas merupakan bagian dari perlengkapan yang biasa digunakan untuk shoping. Tas bagi seorang perempuan merupakan moda dan menjadi koleksi. Pedidikan terakhir perguruan tinggi yang berjumlah sebanyak 54 responden. Hal ini menjelaskan bahwa penggunaan tas Elizabeth cenderung digunakan oleh kalangan dengan pendidikan tinggi. Hal ini dikarenakan kalangan pendidikan tinggi mengerti mengenai kualitas dan brand dari tas Elizabeth. Elizabeth merupakan produsen tas yang berkualitas dengan menyediakan banyak ragam pilihan sesuai dengan trend. Pekerjaan responden terbanyak ialah responden dengan profesi sebagai pegawai swasta yang berjumlah sebanyak 28 responden. Hal ini menjelaskan bahwa tas Elizabeth banyak digunakan dari kalangan pegawai swasta. Profesi berkaitan dengan daya beli. Tas Elizabeth dengan kualitas terbaik cenderung memerlukan biaya yang mahal untuk mendapatkannya.

\section{Analisis Data}

\section{Structural Equation Modeling (SEM)}

Hasil pengujian SEM dengan program AMOS 5, memberikan hasil model persamaan struktural yang menunjukkan hubungan antar variabel seperti disajikan dalam gambar 1 sebagai berikut.

\section{Uji Kesesuaian Model (Goodness of fit Test)}

Hasil pengujian kesesuain model dalam studi ini disajikan dalam Tabel 2.
Tabel 2 Indeks Kesesuaian SEM

\begin{tabular}{llll}
\hline $\begin{array}{l}\text { Kriteria fit } \\
\text { model }\end{array}$ & $\begin{array}{l}\text { Nilai fit } \\
\text { model }\end{array}$ & Standar & $\begin{array}{l}\text { Keterang } \\
\text { an }\end{array}$ \\
\hline X2-chi-square & 440.340 & $\begin{array}{l}\text { Diharapkan lebih } \\
\text { kecil dari X2 pada } \\
\text { df }=85 \text { yaitu } \\
720.345\end{array}$ & Baik \\
Significance & 0,000 & $\geq 0,05$ & Maginal \\
Probability & 0,020 & $\leq 0,08$ & Baik \\
RMSEA & 0,976 & $\geq 0,90$ & Baik \\
GFI & 0,942 & $\geq 0,90$ & Baik \\
AGFI & 2,180 & $\leq 2$ atau 3 & Baik \\
CMIN/DF & 0,987 & $\geq 0,90$ & Baik \\
TLI & 0,923 & $\geq 0,90$ & Baik \\
CFI & 0, &
\end{tabular}

Sumber: Data primer diolah 2016

Berdasarkan Tabel 2 diketahui bahwa dari delapan kriteria yang digunakan untuk menilai baik atau layak tidaknya suatu model ternyata tujuh kriteria terpenuhi dan satu kriteria marginal. Dengan demikian dapat dikatakan model dapat diterima, yang berarti ada kesesuaian antara model dengan data.

\section{Uji Kausalitas}

Langkah selanjutnya adalah menguji kausalitas hipotesis yang dikembangkan dalam model tersebut. Hasil pengujian koefisien jalur disajikan dalam Tabel 3. Dan dari model yang sesuai, maka dapat diimplementasikan masing-masing koefisien jalur.

Tabel 3 Hasil Pengujian Kausalitas

\begin{tabular}{lllll}
\hline Hipotesis & $\begin{array}{l}\text { Koefisien } \\
\text { Jalur }\end{array}$ & CR & Probabilitas & Keterangan \\
\hline Y1BX1 & 3,253 & 2,710 & 0,007 & Signifikan \\
Y2BX1 & 0,844 & 0,365 & $* * *$ & Signifikan \\
Y1BX2 & 0,204 & 1,108 & 0,01 & Signifikan \\
Y2BX2 & 1,832 & 3,474 & $* * *$ & Signifikan \\
Y2ßY1 & 0,431 & 0,604 & 0,021 & Signifikan \\
\hline
\end{tabular}

Sumber: Data primer diolah tahun 2016

Berdasarkan Tabel 3, interpretasi masing-masing koefisien jalur adalah sebagai berikut:

Hipotesis 1 :Merek berpengaruh signifikan terhadap kepercayaan konsumen produk tas Elizabeth di kota Jember.

Merek berpengaruh signifikan terhadap loyalitas pelanggan produk tas Elizabeth di kota Jember, yang terlihat dari koefisien jalur positif sebesar 0.844 dengan C.R sebesar 
0,365 dan diperoleh probabilitas signifikan (p) *** (mendekati nilai nol) yang masih di bawah batas yang distandartkan yaittu 0,05 . Artinya merek produk tas Elizabeth di kota Jemberberpengaruh signifikan terhadap loyalitas pelanggan, yang berarti bahwa jika persepsi akan merek meningkat, maka akan meningkatkan pula loyalitas pelanggan Elizabeth, sebaliknya jika persepsi akan merek menurun maka akan menurunkan persepsi akan loyalitas pelanggan. Hasil ini menerima hipotesis ke dua yang berarti Merek berpengaruh signifikan terhadap loyalitas pelanggan produk tas Elizabeth di kota Jember.

Hipotesis 2 :Kualitas produkberpengaruh signifikan terhadap kepercayaan konsumen produk tas Elizabeth di kota Jember.

Merek berpengaruh signifikan terhadap kepercayaan konsumen produk tas Elizabeth di kota Jember, yang terlihat dari koefisien jalur positif sebesar 3,253 dengan C.R sebesar 2,710 dan diperoleh probabilitas signifikan (p) 0,007 yang masih di bawah batas yang distandartkan yaittu 0,05 . Artinya merek produk tas Elizabeth di kota Jemberberpengaruh signifikan terhadap kepercayaan konsumen, yang berarti bahwa jika persepsi akan merekmeningkat, maka akan meningkatkan pula kepercayaan konsumen Elizabeth, sebaliknya jika persepsi akan merekmenurun maka akan menurunkan persepsi akan kepercayaan konsumen. Hasil ini menerima hipotesis satu yang berarti Merek berpengaruh signifikan terhadap kepercayaan konsumen produk tas Elizabeth di kota Jember.

Hipotesis 3 :Merek berpengaruh signifikan terhadap loyalitas pelanggan produk tas Elizabeth di kota Jember.

Kualitas produk berpengaruh signifikan terhadap kepercayaan konsumen produk tas Elizabeth di kota Jember, yang terlihat dari koefisien jalur positif sebesar 0,204 dengan C.R sebesar 1,108 dan diperoleh probabilitas signifikan (p) 0,01 yang masih di bawah batas yang distandartkan yaittu 0,05 . Artinya kualitas produk tas Elizabeth di kota Jemberberpengaruh signifikan terhadap kepercayaan konsumen, yang berarti bahwa jika persepsi akan kualitas produkmeningkat, maka akan meningkatkan pula kepercayaan konsumen Elizabeth, sebaliknya jika persepsi akan kualitas produkmenurun maka akan menurunkan persepsi akan kepercayaan konsumen. Hasil ini menerima hipotesis ketiga yang berarti kualitas produkberpengaruh signifikan terhadap kepercayaan konsumen produk tas Elizabeth di kota Jember.

Hipotesis 4 :Kualitas produkberpengaruh signifikan terhadap loyalitas pelanggan produk tas Elizabeth di kota Jember.

Kualitas produkberpengaruh signifikan terhadap loyalitas pelanggan produk tas Elizabeth di kota Jember, yang terlihat dari koefisien jalur positif sebesar 1,832 dengan C.R sebesar 3,474dan diperoleh probabilitas signifikan (p) *** (mendekati nol) yang masih di bawah batas yang distandartkan yaittu 0,05. Artinya kualitasproduk tas Elizabeth di kota Jemberberpengaruh signifikan terhadap loyalitas pelanggan, yang berarti bahwa jika persepsi akan kualitas produkmeningkat, maka akan meningkatkan pula loyalitas pelanggan Elizabeth, sebaliknya jika persepsi akan kualitas produkmenurun maka akan menurunkan persepsi akan loyalitas produk. Hasil ini menerima hipotesis ke empat yang berarti kualitas produkberpengaruh signifikan terhadap loyalitas pelanggan produk tas Elizabeth di kota Jember.

Hipotesis 5 :Kepercayaan konsumen berpengaruh signifikan terhadap loyalitas pelanggan produk tas Elizabeth di kota Jember.

Kepercayaan konsumen berpengaruh signifikan terhadap loyalitas pelanggan produk tas Elizabeth di kota Jember, yang terlihat dari koefisien jalur positif sebesar 0,431 dengan C.R sebesar 0,604 dan diperoleh probabilitas signifikan (p) 0,021 yang masih di bawah batas yang distandartkan yaittu 0,05 . Artinya kepercayaan konsumen produk tas Elizabeth di kota Jember berpengaruh signifikan terhadap loyalitas pelanggan, yang berarti bahwa jika persepsi akan kepercayaan konsumen meningkat, maka akan meningkatkan pula loyalitas pelanggan Elizabeth, sebaliknya jika persepsi akan kepercayaan konsumen menurun maka akan menurunkan persepsi akan loyalitas pelanggan. Hasil ini menerima hipotesis kelima yang berarti kepercayaan konsumen berpengaruh signifikan terhadap loyalitas pelanggan produk tas Elizabeth di kota Jember.

Analisis Komparasi Pengaruh Langsung dan Tidak langsung

\section{Pengaruh Langsung Antar Variabel}

Tabel 4 Pengaruh Langsung Variabel Laten

\begin{tabular}{lrrrrr}
\hline \multirow{2}{*}{ Pengaruh Langsung } & \multicolumn{4}{c}{ Variabel Eksogen } \\
\cline { 2 - 6 } & $\mathrm{X} 2$ & $\mathrm{X} 1$ & Y1 & Y2 \\
\hline Variabel Endogen & Y1 &, 120 & 1,085 &, 000 &, 000 \\
Y2 & 1,022 &, 267 &, 409 &, 000 \\
\hline
\end{tabular}

Sumber : Data primer diolah tahun 2016

\section{Pengaruh Tidak Langsung Variabel Laten}

Tabel 5 Pengaruh Tidak Langsung Variabel Laten

\begin{tabular}{lrrrrrr}
\hline \multirow{2}{*}{ Pengaruh Langsung } & & \multicolumn{5}{c}{ Variabel Eksogen } \\
\cline { 5 - 7 } \cline { 5 - 7 } & & X2 & X1 & Y1 & Y2 \\
\cline { 1 - 3 } Variabel Endogen & Y1 & 000 &, 000 &, 000 &, 000 \\
& Y2 &, 049 &, 443 &, 000 &, 000 \\
\hline
\end{tabular}

Sumber : Data primer diolah tahun 2016

\section{Pengaruh Total Antar Variabel Laten}

Tabel 6 Pengaruh Total Antar Variabel Laten

\begin{tabular}{lccc}
\hline \multirow{2}{*}{$\begin{array}{l}\text { Keteranga } \\
\text { n Variabel }\end{array}$} & $\begin{array}{c}\text { Pengaruh } \\
\text { Langsung }\end{array}$ & $\begin{array}{c}\text { Pengaruh Tidak } \\
\text { Langsung }\end{array}$ & $\begin{array}{c}\text { Pengaruh } \\
\text { Total }\end{array}$ \\
\cline { 2 - 3 } X1 & Y & Y & \\
\cline { 2 - 3 } X2 & 0,267 & 0,443 & 0,710 \\
\hline
\end{tabular}

Sumber : Data primer diolah tahun 2016

Hasil penelitian menunjukkan bahwa pengaruh lansung merek terhadap loyalitas sebesar 0,267 sementara pengaruh tidak lansung merek terhadap loyalitas sebesar 0,443 melalui kepercayaan. Hal ini menjelaskan bahwa pengaruh tidak langsung lebih tinggi dari pada pengaruh lansung, artinya dalam membentuk loyalitas memerlukan peranan dari merek 
dan kepercayaan karena jika hanya merek tanpa kepercayaan maka loyalitas konsumen lebih rendah. Hasil penelitian menunjukkan bahwa pengaruh lansung kualitas terhadap loyalitas sebesar 1,022 sementara pengaruh tidak lansung kualitas terhadap loyalitas sebesar 0,049 melalui kepercayaan. Hal ini menjelaskan bahwa pengaruh langsung lebih tinggi dari pada pengaruh tidak lansung, artinya dalam membentuk loyalitas memerlukan peranan dari kualitas yang baik.

\section{Pembahasan}

\section{Pengaruh Merek terhadap Kepercayaan Konsumen Produk Tas Elizabeth di kota Jember}

Hasil pengujian koefisien jalur menunjukkan merek yang terdiri dari enam indikator X1.1 Atribut, X1.2 Manfaat, X1.3 Nilai, X1.4 Budaya, X1.5 Pemakaian, dan X1.6 Kepribadian, berpengaruh positif dan signifikan terhadap kepercayaan konsumen. Merek berpengaruh signifikan terhadap kepercayaan konsumen produk tas Elizabeth di kota Jember. Berdasarkan hasil pengujian tersebut maka hipotesis pertama yang merek berpengaruh signifikan terhadap kepercayaan konsumen produk tas Elizabeth di kota Jember (diterima).

Hasil penelitian ini sesuai dengan pendapat Halim (2002: 3) Jika suatu merek mampu memenuhi harapan konsumen atau bahkan melebihi harapan konsumen dan memberikan jaminan kualitas pada setiap kesempatan penggunaannya, serta merek tersebut diproduksi oleh perusahaan yang memiliki reputasi, maka konsumen akan semakin yakin dengan pilihannya dan konsumen akan memiliki kepercayaan pada merek, menyukai merek serta menganggap merek tersebut sebagai bagian dari dirinya. Sehingga kesetiaan merek akan lebih mudah untuk dibentuk dan perusahaan akan memiliki "frencaiz" konsumen yaitu nama merek yang memiliki kesetiaan konsumen yang kuat, karena kepercayaan merek (brand trust) akan menentukan kesetiaan konsumen terhadap merek dan kepercayaan berpotensi menciptakan hubungan-hubungan yang bernilai tinggi.

Hasil penelitian ini mendukung penelitian dari Penelitian Anggraini (2013) menunjukkan bahwa kualitas, citra dan merek secara signifikan berpengaruh terhadap loyalitas pelanggan kartu prabayar IM3 (Studi pada Mahasiswa FISIP Universitas Diponegoro Semarang). Dari penelitian yang telah dilakukan dapat dijelaskan bahwa penelitian

\section{Pengaruh Kualitas produk terhadap kepercayaan konsumen produk tas Elizabeth di kota Jember}

Hasil pengujian jalur menunjukkan kualitas produkyang terdiri dari tiga indikator yaitu: X2.1 Performa, X2.2 Keistimewaan, dan X2.3 Estetika. Kualitas produk berpengaruh signifikan terhadap kepercayaan konsumen produk tas Elizabeth di kota Jember. Berpengaruh positif dan signifikan terhadap kepercayaan konsumen, hal ini menerima hipotesis ketiga yaitu kualitas produk berpengaruh signifikan terhadap kepercayaan konsumen produk tas Elizabeth di kota Jember (diterima).

Menurut Stefanus (2008) kepercayaan konsumen merupakan sebuah jenis refleksi emosional bagi perdagangan. Hal tersebut tergantung pada tingkat pemenuhan produk yang diharapkan atau layanan manfaat, serta tingkat konsistensi harapan dan hasil aktual. Apabila konsumen mengharapkan suatu produk pada tingkat tertentu, dan yang dirasakannya produk yang diterima lebih tinggi dari apa yang diharapkannya dan tetap menggunakan produk tersebut, maka konsumen tersebut dapat dikatakan percaya. Demikian pula apabila konsumen mengharapkan suatu tingkat produk tertentu, dan pada kenyataannya konsumen tersebut merasakan bahwa produk yang diterimanya sesuai dengan harapannya, maka konsumen tersebut dapatlah dikatakan puas. Sebaliknya, bila kualitas produk yang diterima lebih rendah dari kualitas produk yang diharapkan, maka konsumen tersebut akan dikatakan sebagai konsumen yang tidak puas sehingga konsumen tersebut tidak akan percaya terhadap suatu produk atau dengan kata lain kecewa.

\section{Pengaruh Merek terhadap loyalitas pelanggan produk tas Elizabeth di kota Jember}

Hasil pengujian koefisien jalur menunjukkan merekyang terdiri dari enam indikator, berpengaruh positif dan signifikan terhadap loyalitas pelanggan.Merek berpengaruh signifikan terhadap loyalitas pelanggan produk tas Elizabeth di kota Jember, yang terlihat dari koefisien jalur positif. Berdasarkan hasil pengujian tersebut maka hipotesis kedua yang merek berpengaruh signifikan terhadap loyalitas pelanggan produk tas Elizabeth di kota Jember (diterima).

Hasil penelitian ini sesuai dengan pendapat Chauduri \& Holbrook, (2001) kepercayaan merupakan faktor yang sangat penting dalam mengubah pembeli atau konsumen menjadi pelanggan pertama kali. Konsumen yang percaya pada suatu merek, cenderung akan mempercayakan masalahnya pada merek tersebut. Kepercayaan konsumen terhadap merek (brand trust) akan berdampak terhadap kesetiaan sikap ataupun perilaku konsumen terhadap suatu merek. Hasil penelitian ini tidak sependapat dengan penelitian yang telah dilakuka oleh Penelitian Anggraini (2013) menunjukkan bahwa kualitas, citra dan merek secara signifikan berpengaruh terhadap loyalitas pelanggan kartu prabayar IM3 (Studi pada Mahasiswa FISIP Universitas Diponegoro Semarang).

\section{Pengaruh Kualitas produk terhadap loyalitas pelanggan produk tas Elizabeth di kota Jember}

Hasil pengujian jalur menunjukkan kualitas layanan yang terdiri daritiga indicator.Kualitas produkberpengaruh signifikan terhadap loyalitas pelanggan produk tas Elizabeth di kota Jember, yang terlihat dari koefisien jalur positif. Produk berpengaruh signifikan terhadap loyalitas pelanggan produk tas Elizabeth di kota Jember, hal ini menerima hipotesis keempat (diterima).

Menurut Tjptono (2007:258) menyatakan bahwa kualitas produk yang berarti barang ataupun jasa berkontribusi besar pada kepuasa pelanggan, retensi pelanggan, loyalitas pelanggan, pangsa pasar, dan profitabilitas yang diperkuat dengan hasil studi yang menunjukan bahwa pangsa pasar dan perputaran asset sangat terkait dengan persepsi terhadap kualitas barang pada suatu perusahaan. Hasil penelitian ini mendukung penelitian yang dilakukan oleh Penelitian Anggraini (2013) menunjukkan bahwa kualitas, citra dan merek secara signifikan berpengaruh terhadap loyalitas pelanggan kartu prabayar IM3 (Studi pada Mahasiswa FISIP Universitas Diponegoro Semarang). 


\section{Pengaruh Kepercayaan konsumen terhadap loyalitas pelanggan produk tas Elizabeth di kota Jember}

Hasil pengujian jalur menunjukkan kepercayaan konsumen yang terdiri dari tiga indikator yaitu: Y1.1 Kemampuan, Y1.2 Kebaikan, dan Y1.3 Integritas. Kepercayaan konsumen berpengaruh signifikan terhadap loyalitas pelanggan produk tas Elizabeth di kota Jember. Berpengaruh positif dan signifikan terhadap loyalitas pelanggan produk tas Elizabeth di kota Jember, hal ini menerima hipotesis kelimat Kepercayaan konsumen berpengaruh signifikan terhadap loyalitas pelanggan produk tas Elizabeth di kota Jember (diterima).

Menurut Gilliland dan Bello (2002) mempertimbangkan kaitan antara kepercayaan, komitmen dan loyalitas, dan hasil studi Gilliland dan Bello (2002) menunjukkan kepercayaan pelanggan merupakan anteseden dari komitmen dan loyalitas pelanggan. Hasil penelitian ini tidak sependapat dengan penelitian yang telah dilakukan. Penelitian Maharani (2010) menunjukkan bahwa kepercayaan dan kepuasan secara signifikan berpengaruh terhadap loyalitas nasabah tabungan bank Mega Semarang.

\section{Pengaruh langsung dan tidak langsung merek dan kualitas produk terhadap kepercayaan dan loyalitas pelanggan produk tas Elizabeth di kota Jember}

Hasil penelitian menunjukkan bahwa pengaruh lansung merek terhadap loyalitas sebesar 0,267 sementara pengaruh tidak lansung merek terhadap loyalitas sebesar 0,443 melalui kepercayaan. Hal ini menjelaskan bahwa pengaruh tidak langsung lebih tinggi dari pada pengaruh lansung, artinya dalam membentuk loyalitas memerlukan peranan dari merek dan kepercayaan karena jika hanya merek tanpa kepercayaan maka loyalitas konsumen lebih rendah. Hasil penelitian menunjukkan bahwa pengaruh lansung kualitas terhadap loyalitas sebesar 1,022 sementara pengaruh tidak lansung kualitas terhadap loyalitas sebesar 0,049 melalui kepercayaan. Hal ini menjelaskan bahwa pengaruh langsung lebih tinggi dari pada pengaruh tidak lansung, artinya dalam membentuk loyalitas memerlukan peranan dari kualitas yang baik.

Berdasarkan pada karakteristik responden diketahui bahwa responden sebagian besar adalah perempuan 72 responden. Hal ini menjelaskan bahwa tas Elizabeth banyak digunakan oleh perempuan. Tas berkaitan dengan gaya hidup dan kebiasaan yang sering dilakukan oleh perempuan yaitu shoping. Tas merupakan bagian dari perlengkapan yang biasa digunakan untuk shoping. Tas bagi seorang perempuan merupakan moda dan menjadi koleksi. Selain itu sebagian besar berpedidikan terakhir perguruan tinggi yang berjumlah sebanyak 54 responden. Hal ini menjelaskan bahwa penggunaan tas Elizabeth cenderung digunakan oleh kalangan dengan pendidikan tinggi. Hal ini dikarenakan kalangan pendidikan tinggi mengerti mengenai kualitas dan brand dari tas Elizabeth. Elizabeth merupakan produsen tas yang berkualitas dengan menyediakan banyak ragam pilihan sesuai dengan trend. Selanjutnya berdasarkan pada profesi sebagian besar adalah pegawai swasta yang berjumlah sebanyak 28 responden. Hal ini menjelaskan bahwa tas Elizabeth banyak digunakan dari kalangan pegawai swasta. Profesi berkaitan dengan daya beli. Tas Elizabeth dengan kualitas terbaik cenderung memerlukan biaya yang mahal untuk mendapatkannya.

Hasil penelitian ini memberikan gambaran bahwa kualitas produk sangat menjadi pertimbangan bagi konsumen dalam membentuk loyalitas ataupun kepercayaan dari merek. Artinya konsumen lebih memepertimbangkan kualitas produk dari pada merek dalam melakukan pembelian ataupun membentuk keyakinan atau kepercayaan pada produk. Kualitas dalam suatu produk penting karena berkaitan dengan jumlah biaya yang dikeluarkan serta daya tahan dalam penggunaan jangka lama. Konsumen jelas mencari produk yang awet atau berkualitas baik dibandingkan dengan memilih merek. Jika dikaitkan dengan karakteristik responden yang dominan perempuan, mahasiswa serta bekerja sebagai wiraswasta maka kualitas menajadi pertimbangan utama dalam melakukan pembeliaan, karena mahasiswa cenderung selektif dalam memutuskan sesuatu artinya masih membandingkan dengan produk lainnya, serta memiliki tingkatkan kebutuhan akan tas yang awet untuk kepentingan sehari-hari seperti kuliah shoping dan sebaginya. Selanjutnya pekerjaan konsumen menentukan tingkat kemampuan dalam melakukan pembelian.

\section{Simpulan}

Berdasarkan hasil penelitian dapat disimpulkan bahwa bahwa merek dan kualitas produk berpengaruh terhadap kepercayaan pelanggan dan loyalitas pelanggan produk tas Elizabeth di wilayah Kota Jember.

\section{Referensi}

Astri Dhiah Maharani. 2010. Analisis Pengaruh Kepercayaan Dan Kepuasan Terhadap Loyalitas Nasabah Tabungan Bank Mega Semarang. Tidak dipublikasikan. Skripsi. Semarang: Fakultas Ekonomi Universitas Diponegoro.

Chaudhuri, A., \& Holbrook, M. B. (2001). The Chain of Effects from Brand Trust and Brand Affect to Brand Performance: The Role of Brand Loyalty. Journal of Marketing, Vol. 65, April, pp. 81-93.

FandyTjiptono 2007, Strategi Pemasaran. Edisi ke dua, penerbit Andi,. Yogyakarta.

Ferdinand, Augusty. 2006. Metode penelitian manajemen Edisi 2. Badan Penerbit Universitas di Ponegoro, Semarang

Freddy Rangkuti. 2002. Riset Pemasaran. Gramedia Pustaka Utama, Jakarta.

Gilliland, David I. \& Bello, Daniel C. 2002, Two sides to Attitudinal Commitment: The Effect of Calculative and Loyalty Commitment on Enforcement Mechanism in Distribution Channels, Journal of the Academy of Marketing Science Vol. 30 No. 1

Kotler, Philip. 1997. Manajemen pemasaran, Edisi Milenium. PT Prenhalindo. Jakarta

Kotler, Philip. 2000. Manajemen pemasaran, Edisi Milenium: PT Prenhalindo, Jakarta

Lau.Geok Then and Sook Han Lee.1999.Consumers Trust in a Brand and the Link to Brand Loyalty...Journal of Market Focused Management. 4. pp 341- 370 .

Morgan, R.M \& Hunth, S.D. 1994.The Comitment-Trust Theory of Relationship Marketing. Journal of Marketing 58(3), 20-38.

Mouren, Margaretha. 2004. Studi Mengenai Loyalitas Pelanggan Pada Devisi Asuransi Kumpulan AJP Bumi Putra. Jurnal Sains Pemasaran Indonesia. Vol.iii, No 3, halaman 289-308.

Muhammd Dimyati. 2004. Perilaku Konsumen Jilid 2. Diktat Kuliah. Fakultas Ekonomi Universitas Jember. Jember:

Philip Kotler. 1997. Manajemen Pemasaran. Grafika Indo, Jakarta

Rizal Edy Halim, 2002. Dampak Hubungan kepercayaan merek Dan afeksi Merek terhadap Kinerja Merek, Jurnal Manajemen Indonesia Vol. 1, no. 2. Jakarta.

Rr. Anisa Anggraini 2013.Pengaruh Kualitas produk, Citra Dan Merek Terhadap Loyalitas Pelanggan Kartu Prabayar IM3 (Studi Pada Mahasiswa FISIP Universitas Diponegoro Semarang). Tidak 
